DOI https://doi.org/10.30525/978-9934-588-91-4-3

\title{
АКТУАЛІЗАЦІЯ КОМУНІКАТИВНОГО ПОТЕНЦІАЛУ МІЖДИСЦИПЛІНАРНИХ ДОСЛІДЖЕНЬ
}

\author{
Манчул Б. В. \\ кандидат філософських наук \\ викладач кафедри психології та філософії \\ Буковинського держаного медичного університету \\ м. Чернівиі, Україна
}

Актуальність аналізу комунікативних аспектів сучасних міждисциплінарних досліджень зумовлена декількома важливими чинниками.

По-перше, це новітні тенденції розвитку філософії та методології науки, в структурі якої проблематика міждисциплінарної комунікації в останні десятиліття посідає чільне місце. Зазвичай прихильники міждисциплінарного підходу вважають, що традиційні дисципліни неспроможні розв'язувати нагальні проблеми, оскільки $є$ занадто диференційованими й тому маргінальними у своїх дослідженнях.

По-друге, йдеться про дискусії з приводу визначення самого поняття міждисциплінарності. В широкому розумінні воно означає загальну назву різноманітних форм інтеграції дисциплінарного наукового знання (крос-, полі, трансдисциплінарність тощо), тоді як у вузькому значенні міждисциплінарність - це поєднання методів двох або більше дисциплін у єдиний дослідницький проект аж до можливості виникнення нової дисципліни (біохімія, соціальна психологія тощо).

По-третє, набуває поширення переконання, що цей підхід потребує ширшої методології, хоча й досі незрозуміло, якою вона повинна бути. Крім того, досить часто в бік учених-міждисциплінарників лунають звинувачення у дилетантстві.

По-четверте, міждисциплінарність нерозривно пов'язана 3 дисциплінарністю. Нагальною проблемою стала відсутність єдиної термінології у сфері міждисциплінарного дискурсу, тому зазвичай використовується вузько-дисциплінарна мова, яка не завжди може відобразити суть означеного дослідження.

По-п’яте, зміщення в бік міждисциплінарних підходів в отриманні нового знання може змінити наукову парадигму, тому роль філософії та методології науки зростає. 3'являються такі нові поняття, як «міждисциплінарний спеціаліст», «міждисциплінарна команда», «міждисциплінарна спільнота» тощо, в осмисленні яких комунікативні параметри міждисциплінарності набувають вирішального значення [3].

По-шосте, міждисциплінарний підхід не завжди враховує той факт, що знання, створене в різних парадигмах, може бути несумірним. 
Історично міждисциплінарні процеси у сфері гуманітарнонаукового знання мали на меті узагальнити постійно зростаючий обсяг знань, тому простежується еволюція від методологічного плюралізму до спроби побудови міждисциплінарної методології [2]. Відсутність єдиної міждисциплінарної методології гуманітарно-наукового знання спонукала до розробки такої системи методів, які у свою чергу призвели до уточнення понять «пізнання», «розуміння», «тлумачення», «істина» тощо.

Незважаючи на стрімке зростання міждисциплінарного складника в отриманні нового знання, дисциплінарна структура науки залишається домінантною, тому виникає потреба у створенні «комунікативних мостів» між цими двома підходами. Комунікативний поворот став одним із чинників формування міждисциплінарного гуманітарнонаукового дискурсу. Перехід до проблемно-орієнтованих наукових стратегій призвів до акцентуації уваги вчених на плюралізмі підходів, діалогічності мислення та комунікативних практиках. Водночас переосмислюється феномен наукового консенсусу. Специфічні риси міждисциплінарних комунікацій у постнекласичній науці розкривають ціннісну релевантність наукового знання. Акцент робиться на синергетичному розумінні розвитку науки i культури. Гуманітарні науки зосереджуються на розумінні, цінностях, сенсі людського життя (пережитому досвіді) [1]. Тому міждисциплінарна комунікація підгрунтя й один із ефективних засобів створення моделі науки, яка враховує людиномірність і полілогічність пізнання.

\section{Література:}

1. Bhaskar R., Denermark B., Price L. Interdisciplinarity and Wellbeing: A Critical General Theory of Interdisciplinarity. Taylor \& Francis, 2017. 174 p.

2. Epstein M. The Transformative Humanities: A Manifesto. N. Y, 2012. $272 \mathrm{p}$.

3. Olteanu A., Stables A., Borţun D. Meanings \& Co. : the Interdisciplinarity of Communication, Semiotics and Multimodality. Springer, 2019. $270 \mathrm{p}$. 